\title{
O SOLO URBANO E A APROPRIAÇÃO DA NATUREZA NA CIDADE
}

\author{
The ground urban and the appropriation of the nature in the city
}

\author{
Adauto Gomes Barbosa \\ Doutorando em Geografia, UFPE. Professor do IFPE Pernambuco \\ adautogb@gmail.com \\ Ademir Araújo da Costa \\ Professor Associado, Depto. de Geografia, UFRN \\ ademir@ufrnet.br
}

Artigo recebido em 16/07/2012 e aceito para publicação em 13/08/2012

RESUMO: O artigo analisa a inserção do solo urbano como alvo da atuação dos promotores imobiliários, bem como a apropriação da natureza sob o aspecto mercadológico, tendo como recorte espacial de investigação o Litoral Sul de João Pessoa, capital do Estado da Paraíba, Brasil. A organização espacial de uma base fundiária urbana envolve intervenções tais como desmatamento, arruamento, desmembramentos de loteamentos já existentes, terraplanagem, delimitação das áreas destinadas à construção de equipamentos comunitários, dentre outras. Na cidade, o solo constitui condição geral de reprodução do capital e da sociedade e não um meio de produção como acontece na agricultura. Portanto, é uma mercadoria sui generis uma vez que é irreproduzível e passível de monopolização pelos seus proprietários. Tomando por base o recorte territorial da pesquisa, o artigo discute a extração dos três tipos de renda fundiária urbana: a renda absoluta, a diferencial e a de monopólio. Em, seguida, a natureza é abordada como mercadoria no espaço urbano em decorrência de ser uma nova raridade. Porém, a apropriação desse produto raro passa a ser privilégio de uns poucos, ou seja, daqueles que podem pagar o alto preço dos lotes "servidos" pelas amenidades naturais. Essa "mercadoria verde" se torna um fator de valorização do espaço urbano e passa a se constituir num dos apelos mercadológicos para a venda de lotes nos condomínios fechados horizontais, muito embora, nesses espaços, não haja propriamente um convívio com a natureza, pois ela representa um mero simulacro.

Palavras-chave: solo urbano; renda fundiária urbana; apropriação da natureza; condomínios fechados horizontais; João Pessoa.

ABSTRACT: The article analyzes the insertion of the urban land as a target for the action of real estate companies, as well as the appropriation of nature under the marketing aspect, focusing on the south littoral of João Pessoa, capital city of the State of Paraíba, Brazil. The spatial organization of all lands in the urban space involves interventions such as deforestation, opening of streets, dismemberment of existing plots of land, earthwork, delimitation of areas destined to the construction of community facilities, among others. In the city, the land is general condition for reproduction of capital and society not a means of production as happens in agriculture. Thus, it is a sui generis merchandise once it is unique and liable for monopolization by its owners. Taking into account the subject of the research, the article discusses the extraction of the three types of urban land rent: absolute, differential and monopolist. Later, nature is mentioned as merchandise in the urban space because it is a new rarity. However, the appropriation of this rare merchandise becomes a privilege of a few, this is, of those who can pay high prices for the lands "served" by the natural amenities. This "green merchandise" becomes a factor for the valorization of the urban space and constitutes one of the marketing appeals for the negotiation of lands in gated communities, although in these spaces there is no coexistence with nature, for it represents a mere simulacrum. Keywords: Urban land; urban land income; appropriation of nature; horizontal gated condominium; João Pessoa. 


\section{INTRODUÇÃO}

O presente artigo analisa a inserção do solo urbano como alvo da atuação dos promotores imobiliários, bem como a apropriação da natureza sob o aspecto mercadológico, tendo como recorte espacial de análise o Litoral Sul de João Pessoa.

O solo urbano constitui uma mercadoria muito disputada pelos agentes capitalistas que produzem a cidade. Por meio de suas ações, esses agentes controlam, orientam e dão significado ao crescimento e reestruturação do espaço urbano.

Dentre as características do Litoral Sul da cidade de João Pessoa, capital do Estado da Paraíba, ressalta-se a baixa densidade urbana e a presença de certas amenidades naturais, como manchas da vegetação original e a proximidade do mar. O Altiplano do Cabo Branco, onde está localizada a área investigada, é tratado na legislação urbanística municipal e na Constituição Estadual, como área de interesse ambiental e paisagístico, sendo classificada como zona de restrição adicional. Contudo, nos últimos anos, foi transformado em novo alvo do capital imobiliário, por meio da abertura de loteamentos para implantação de Condomínios Fechados Horizontais (CFHs) e a consequente transformação de solo rural em urbano, alterando sobremaneira a sua composição social e econômica.

Diante de tais características, o convívio com a natureza passa a figurar no discurso dos promotores imobiliários, bem como no de moradores dos $\mathrm{CFHs}$, como uma imagem criada por meus dos anúncios publicitários em referência ao Litoral Sul de João Pessoa. A recorrência às contribuições teóricas de Henri Lefebvre é um importante aporte conceitual para interpretar o sentido dessas práticas e, ao mesmo tempo, refletir sobre os desafios a serem enfrentados pelos gestores urbanos, no que tange às mudanças no zoneamento do uso do solo com vistas à manutenção das poucas áreas verdes da cidade. Essas e outras questões que têm como cerne a cidade enquanto mercadoria são aqui abordadas, sempre com a ideia de que a discussão continua aberta para o debate e a reflexão.

\section{O SOLO URBANO E A EXTRAÇÃO DA RENDA FUNDIÁRIA}

O estudo da problemática urbana relativa à terra enquanto mercadoria demanda o exame das ações exercidas pelo conjunto dos agentes produtores do espaço urbano, pois elas são reveladoras das suas estratégias, iniciativas e distintos interesses. Nas cidades produzidas sob a lógica capitalista, o solo urbano assume claramente a condição de mercadoria. Em face dessa questão, muitos problemas que emergem na cidade possuem uma forte dimensão espacial.

Segundo Harvey (1980), o solo urbano é uma mercadoria bastante peculiar. Seis aspectos são levantados por este autor:

i. o solo urbano e suas benfeitorias apresentam uma localização absoluta, uma vez que não podem ser deslocado.

ii. o solo e suas benfeitorias são mercadorias indispensáveis à reprodução da força de trabalho, à produção de bens e ao suprimento das necessidades de todos os indivíduos, tais como morar, trabalhar, divertir-se e tantas outras, funcionando como o sustentáculo de reprodução social e das condições de existência. A realização da produção e do consumo demanda, pois, de solo;

iii. o solo e as benfeitorias apresentam uma rotatividade de mão em mão muito pouco frequente, ou seja, são vendidos e comprados com menor frequência e a sua aquisição se dá em intervalos de tempo bem maiores do que as outras mercadorias. Trata-se, assim, de um bem bastante duradouro. Os investimentos em capital fixo como infraestruturas e a própria casa têm uma durabilidade muito longa e envolvem alto custo ou ainda têm uma natureza de funcionamento bastante peculiar, não se prestando a uma comercialização frequente;

iv. o solo constitui algo permanente e sob certos aspectos é indestrutível. Em outros termos, "[...] não requer ser mantido em ordem para continuar com seu potencial de uso" (HARVEY, 1980, p. 136). Numa economia capitalista, ele se apresenta como um valor de uso presente e um valor de troca potencial, para o futuro.

v. muito embora a troca ocorra em um dado momento, o uso do solo e de suas benfeitorias se es- 
tende por um longo período de tempo, o que implica dizer que o solo urbano apresenta ciclo de rotação do capital muito longo. Sposito (1991) assevera que o seu consumo pode ser temporariamente absoluto ou relativo. O primeiro caso ocorre quando o uso dos imóveis se dá por meio da compra e "pelo tempo em que estiver como proprietário do imóvel, a ele tem-se direito único, absoluto e o monopólio de decidir sobre seu uso" (SPOSITO, 1991, p. 154-155). De outro modo, o direito de uso é relativo ou provisório quando é permeado pelo aluguel do imóvel;

vi. o solo e suas benfeitorias têm usos diferentes, numerosos e não necessariamente excludentes entre si, ainda que ocorram ao mesmo tempo.

Conforme salientou Singer (1980, p. 79), "a 'produção' de espaço urbano se dá, em geral, pela incorporação à cidade de glebas que antes tinham uso agrícola" (grifo do autor). Assim, à proporção em que há o aumento da demanda por terras, os agentes produtores do espaço urbano promovem a agregação de novas terras à cidade. Com efeito, ocorre $\mathrm{a}$ ampliação da mancha urbana.

É importante considerar que o processo de expansão urbana resultante da anexação de novos recortes territoriais à cidade implica numa contínua redefinição dos usos do solo e uma reestruturação urbana. Neste ponto, enquanto agente produtor do espaço urbano, o Estado assume papel de grande relevo. É ele o principal provedor de infraestrutura e serviços e estabelece o marco jurídico referente à ocupação e uso do solo, interferindo de forma direta e indireta na atuação dos demais agentes, a exemplo dos incorporadores e construtores.

Nessa expansão, são várias as etapas de preparação do solo urbano para receber a instalação de inúmeros objetos imobiliários que compõem a cidade. Assim, a organização espacial de uma base fundiária urbana envolve intervenções tais como desmatamento, arruamento, desmembramentos de loteamentos já existentes, terraplanagem, delimitação das áreas destinadas à construção de equipamentos comunitários, dentre outras.

Mas, como o marco jurídico muda ao longo do tempo, é necessário considerar esta variável para analisar as características de uma determinada base fundiária. Neste sentido, no âmbito do Litoral Sul de
João Pessoa, a legislação que norteou a instalação do loteamento Cidade Recreio Cabo Branco, aprovado na Prefeitura Municipal em 1957, não é exatamente a mesma do período da implantação dos loteamentos do Quadramares II e do Cabo Branco Residence Privê, os quais foram aprovados, respectivamente, em 1996 e 1998. Mudanças no zoneamento urbano-ambiental também podem alterar sobremaneira os parâmetros urbanísticos, interferindo de forma decisiva na produção ou reprodução do espaço urbano.

A legislação brasileira referente ao solo urbano é relativamente recente. O parcelamento do solo, por exemplo, é regulamentado pela Lei Federal $n^{\circ}$ 6.766/79 e Lei Federal no 9.785/99 (esta última regulamentou alguns aspectos da lei anterior), o que implica dizer que todos os loteamentos têm de estar em conformidade com esta lei para que seja aprovado pela Prefeitura Municipal. Além disso, é preciso levar em conta o zoneamento urbano-ambiental relativo ao uso do solo, que é estabelecido pelo município em consonância com a legislação federal pertinente.

Para além da questão do marco jurídico urbanístico, é o capital imobiliário que cria e recria as condições para assegurar a sua reprodução no espaço urbano. Nesse processo, não raro, o Estado sofre pressões no sentido de direcionar a provisão de equipamentos e serviços urbanos que geram as vantagens locacionais em determinados fragmentos da cidade. A esse respeito, Campos (apud LOW-BEER, 1983, p. 39) destaca cinco modalidades de ganhos relacionados com a estrutura do mercado imobiliário:

i. ganhos resultantes da retenção, ainda que sem uso de imóveis;

ii. ganhos resultantes das normas legais de zoneamento do solo urbano;

iii. ganhos resultantes do não cumprimento dessa legislação;

iv. ganhos resultantes das inversões promovidas pelo Estado; e, por fim,

v. ganhos resultantes de legislação fiscal inéqua sobre a propriedade urbana.

É importante ressaltar que, na cidade, o solo constitui condição geral de reprodução do capital e da sociedade e não um meio de produção como acontece na agricultura. Diante disso o solo urbano constitui uma mercadoria sui generis uma vez que é 
irreproduzível e passível de monopolização pelos seus proprietários. Por sua irreprodutibilidade e monopolização representa um bem escasso, e para a cidade crescer exige uma contínua expansão por meio da incorporação de terras agrícolas e a sua transformação em terras urbanas. Nesse processo, as qualidades intrínsecas relacionadas à fertilidade natural perdem qualquer importância do ponto de vista do solo urbano.

A mercadoria solo urbano é muito peculiar frente às demais mercadorias no contexto da cidade capitalista. Muitos dos problemas e obstáculos que afetam o dia a dia dos moradores das cidades têm natureza espacial e a sua solução requer a apreciação das distintas virtualidades propiciadas pelo solo, não apenas enquanto valor de uso, mas também como um valor de troca peculiar, no sentido de que é irreproduzível e seu acesso é monopolizável por meio da instituição jurídica da propriedade privada. Diante dessas virtualidades da cidade capitalista, o solo urbano, via de regra, se torna alvo de intensas disputas entre os agentes produtores do espaço.

Um aspecto importante a ser considerado é que o mercado de solo urbano é muito imperfeito. Isso se explica porque o mecanismo da oferta e da procura não se mostra equilibrado. A demanda de solo urbano advém do crescimento populacional e das atividades econômicas na cidade.

Mas, em contrapartida, a oferta de solo apresenta uma rigidez estrutural e, citando as palavras de Topalov (1984, p. 6), decorre dos seguintes aspectos: "escasez física de terrenos dotados de equipamientos públicos, escasez unida a la reglamentación que limita los derechos de construcción, escasez producida artificialmente por la retención especulativa de los propietarios."

Além disso, o aumento da oferta não implica numa automática queda dos preços. Ao contrário, à medida que uma área recebe as inversões promovidas pelo Estado e passa a ser dotada de meios de consumo coletivo, o aumento da oferta de terrenos é acompanhado também do aumento dos preços.

De acordo com Topalov (1984), tal imperfeição do mercado de solo urbano resulta do fato de o valor de uso do solo não ser um produto do trabalho individual. Seguindo tal linha de raciocínio, Singer (1980) afirma que o capital imobiliário representa um falso capital, na medida em que seu valor não é produto do trabalho, inferindo que

O “capital” imobiliário é, portanto, um falso capital. Ele é, sem dúvida, um valor que se valoriza, mas a origem de sua valorização não é a atividade produtiva e sim a monopolização do acesso a uma condição indispensável àquela atividade (SINGER, 1980, p. 77-78, grifo do autor).

Portanto, quando uma determinada parcela de terra é incorporada ao espaço urbano, o preço que é estabelecido para cada lote não tem nada a ver com o custo de sua implantação e menos ainda com a produção agrícola que porventura lá existia antes dessa operação. A partir dos aspectos até aqui assinalados, o solo urbano é na verdade uma mercadoria muito peculiar, pois encerra certas condições fundamentais de reprodução do capital e da sociedade.

De acordo com Lojkine (1979), duas condições são necessárias para a obtenção de renda fundiária urbana: a composição orgânica do capital investido deve ser inferior ao capital social médio e a existência da instituição jurídica da propriedade privada, a qual, na prática, significa a monopolização do controle que o proprietário tem sobre uma dada fração do território da cidade. Em outros termos, a propriedade privada permite a distinção entre os proprietários e os não-proprietários de solo urbano e nesse caso se torna condição fundamental para que os primeiros controlem o acesso à terra e dela extraiam renda.

Portanto, o aspecto central que funda a renda absoluta é a capacidade inerente à propriedade privada da terra de gerar renda para o proprietário. Dessa maneira, a renda absoluta configura uma determinação da propriedade privada, ou seja, o desaparecimento desta instituição jurídica resultaria na impossibilidade de extração de renda absoluta (TOPALOV, 1979). No âmbito da indústria da construção civil, a renda absoluta advém do fato de o valor dos produtos nesta atividade superar a taxa de lucro médio deste setor.

Como o solo é uma mercadoria monopolizável e não reproduzível, a propriedade privada coloca-se como um obstáculo à circulação do capital. Justamente por deter o monopólio do controle da terra, o proprie- 
tário tem total poder de decisão de colocar ou não seu terreno à disposição para aluguel ou arrendamento, com vistas à obtenção de renda absoluta. Ou seja, uma das formas de realização desta modalidade de renda se dá a partir da concessão, por parte do proprietário, do acesso e direito de uso do solo urbano a outrem mediante o pagamento do aluguel. De acordo com Singer (1980), o aluguel constitui a renda absoluta do solo urbano.

Esta possibilidade de obtenção de renda absoluta se consuma apenas na esfera da circulação do capital. Contudo, no que toca à esfera da produção imobiliária, tal modalidade de renda dependerá das relações estabelecidas entre o proprietário e o capital incorporador e construtor "sendo necessário que este repasse àquele uma parte da mais-valia que a venda do imóvel permite realizar"'(SPOSITO, 1991, p. 174). Seguindo tal linha de raciocínio, esse mecanismo representa a renda absoluta no segmento da produção imobiliária. No Litoral Sul de João Pessoa, a presença de grandes estoques de solo urbano ainda não edificado representa a possibilidade de seus proprietários auferirem renda absoluta.

Por seu turno, no espaço urbano, a obtenção de renda diferencial depende das distintas virtualidades geradas pela localização. Assim, "terrenos com as mesmas dimensões, as mesmas características topográficas, terão preços diferentes, dependendo da localização na cidade" (RODRIGUES, 2003, p. 19). Ou seja, a produção social do espaço urbano é que estabelece tal diferenciação intraurbana, possibilitando aos proprietários fundiários extraírem renda diferencial. Isso tem a ver, em grande medida, com as condições de acessibilidade bastante heterogêneas que cada local desfruta no conjunto da cidade.

Nesse sentido, o papel das exterioridades (ou efeitos úteis de aglomeração) é muito importante para se compreender a valorização desigual das inúmeras localizações que compõem o espaço urbano. A presença dos meios de consumo coletivos, tais como: autopistas, rede de água e esgoto e de telefonia, escolas, centros comerciais, bancos, hipermercados, dentre tantos outros, gera vantagens locacionais em comparação a localizações onde a demanda por esses serviços urbanos é muito maior.

A bem da verdade, ao equipar o espaço urbano com a maior parte dos meios de consumo coletivos, o Estado é o agente de maior responsabilidade no processo de valorização desigual das localizações que compõem a cidade capitalista e, por extensão, viabiliza a renda diferencial urbana.

As virtualidades propiciadas por uma dada localização na cidade é o resultado do acúmulo de trabalho social. Para Singer (1980, p. 83),

a renda diferencial é paga pelas empresas tendo em vista o superlucro que cada localização especifica lhe proporciona. A renda paga pelos individuos depende de sua quantidade, da repartição da renda pessoal e de necessidades míticas que a própria promoção imobiliária cria.

Logo, além dos elementos que estruturam o espaço urbano, o "prestígio social" também se torna gerador de renda diferencial, na medida em que é propiciador de necessidades míticas.

Certos bairros e áreas da cidade podem ser reconhecidos como setores preferenciais de moradia da elite e, neste caso, ainda que muitas vezes desprovidos de infraestrutura urbana, são mais valorizadas no mercado imobiliário do que outras localizações que porventura disponham de toda infraestrutura, mas que são identificados como áreas populares. Este é o caso de muitos lotes situados no Litoral Sul, que apresentam carência de infraestrutura, mas que são bem mais caros que outros lotes localizados na periferia da cidade.

Os promotores imobiliários exploram ao máximo esse aspecto, com vistas a obterem sobrelucros de localização. Tal componente simbólico do espaço urbano não deve ser perdido de vista, pois a todo tempo o capital imobiliário influi decisivamente na produção de fragmentos da cidade com o objetivo de auferir rendas diferenciais.

No caso da área de estudo, está muito claro que os CFHs conferem status às suas localizações. Tal aspecto pode ser observado a partir do discurso dos sujeitos da pesquisa, em particular, dos promotores imobiliários e dos moradores desses condomínios.

Até o momento, muitas localizações que compõem a área da pesquisa permitem a extração de renda diferencial, sobretudo em função das amenidades naturais (presença de resquícios de vegetação, o silêncio 
e tranquilidade que ele proporciona e a proximidade do mar), ainda que não se trate propriamente de uma natureza conservada, mas tão somente da presença de elementos residuais.

Todavia, os CFHs representam o principal fator de geração de renda diferencial. Exemplo disto é que os preços dos lotes, nesses condomínios, subiram mais de duzentos por cento desde o lançamento. Segundo os próprios moradores, a tranquilidade oferecida por essa nova forma de moradia em João Pessoa, é um dos seus diferenciais.

É importante ressaltar que a renda diferencial também se origina das condições de construtibilidade do terreno. Essas condições têm a ver tanto com o aspecto da dinâmica natural dos terrenos, a exemplo do grau de declividade e da capacidade de resistir à construção de edificações, quanto em relação a aspectos jurídicos ligados, predominantemente, ao parcelamento do solo urbano, que determinam os índices de ocupação, afastamento, gabaritos de altura máxima, dentre outros.

Nesse sentido, Eliseu Savério Sposito (1990) ressalta que os custos diferenciais na produção de uma edificação não decorrem apenas do avanço das técnicas da construção civil, ou seja, da composição orgânica do capital, mas também dos custos relativos à construtibilidade.

Se se tomar por base as formulações de Lojkine (1979), até o momento só foi feita referência à renda diferencial I, a qual é resultante da localização e das condições de construtibilidade. Ele também denomina a renda diferencial I de renda de situação.

Para o referido autor, a renda diferencial II é gerada a partir da "diferença entre os investimentos capitalistas nos centros comerciais e imóveis para escritórios, logo por suas diferenças de produtividade" (LOJKINE, 1979, p. 85). Neste caso, como o Litoral Sul apresenta uso do solo basicamente residencial, só identificada a renda diferencial I.

$\mathrm{Na}$ cidade, a renda de monopólio deriva de condições muito específicas que determinadas localizações possuem em detrimento das demais. Para Topalov (1984), a renda de monopólio depende da fixação do excedente do preço de mercado acima do preço regulador de um bem cuja localização não pode ser reproduzida. O referido autor ainda acrescenta:
Si los efectos de aglomeración generan uma diferenciación espacial de los costes de producción de los bienes o servicios, las plusganancias que surgen pueden ser fijadas como rendas diferenciales. Si eventualmente las empresas se vem forzadas a ubicar su sede social, por ejemplo, em ciertos emplazamientos únicos o dificiles de sustituir, se pueden formar, entonces, precios de monopolio susceptibles de ser transformados em rentas de monopolio (TOPALOV, 1984, p. 225-226).

Em outros termos, a capacidade que a cidade possui de aglomerar produz condições muito desiguais de valorização de fragmentos de seu espaço, fixando rendas diferenciais e, no limite, rendas de monopólio. Para Singer (1980, p. 81), a renda de monopólio "decorre da existência de localizações que conferem aos que a ocupam o monopólio do fornecimento de determinadas mercadorias" a um determinado público cativo.

O autor aponta como exemplo o caso de lanchonetes, lojas, restaurantes e bares localizados em aeroportos, shopping centers, escolas e similares, que usufruem de condições de monopólio para a venda de suas mercadorias a preços majorados que geram sobrelucros, originando renda de monopólio.

A renda monopolista, na produção imobiliária, advém da capacidade de demanda do mercado com base nas possibilidades que certos estratos socioeconômicos têm de pagar pelos imóveis, preços mais elevados que outros semelhantes, em nome do acesso a localizações que sob certo ponto de vista são tidas como únicas no espaço urbano.

Nesse aspecto, as localizações que guardam relação direta com certos desejos de consumo dos estratos sociais de alto poder aquisitivo são passíveis de sofrerem preços de monopólio. É preciso considerar, no entanto, que as condições que permitem a obtenção de renda de monopólio numa determinada localização, são contingentes a um determinado período histórico.

A realização da renda de monopólio na cidade é sempre expressão de um dado momento histórico, visto que as características que permitem sua realização em determinado terreno 
não são naturais [...], mas historicamente determinadas. É no processo social e histórico de produção da cidade que certas localizações se configuram, em dado momento, como especiais e únicas no que se refere à possibilidade de incorporar um determinado tipo de produção imobiliária (SPOSITO, 1991, p. 178).

Com base nas palavras acima, é preciso reconhecer que, sob uma perspectiva histórica, as condições para a extração da renda de monopólio já se configuraram em maior proporção, na área de estudo, nos períodos de lançamento dos loteamentos. Por meio da apropriação privada de estoques de terra e, portanto, da monopolização criada por essa instituição jurídica, é possível que a comercialização comandada pelos proprietários fundiários tenha resultado na obtenção de renda de monopólio.

Ademais, o exposto pela autora justifica-se até mesmo pelo fato de o espaço urbano aqui ser abordado como uma contingência histórica e social. As condições de rentabilidade proporcionadas pela exploração das localizações acompanham a dinâmica do processo de produção e reprodução do espaço urbano. Desse modo, o lugar de monopólio é criado e recriado em diversos momentos e em distintos fragmentos da cidade.

\section{ANATUREZA NO ESPAÇO URBANO E A CRIA- ÇÃO DE "NOVAS RARIDADES"}

A condição de raridade assumida pela natureza no espaço urbano parte do fato de que os bens naturais que em tempos pretéritos eram abundantes estão cada vez mais escassos (LEFEBVRE, 1976) e se convertem em mercadoria. A escassez desses bens é efeito do crescimento da cidade e da produção capitalista. Nesse sentido, as amenidades naturais, tais como: a vegetação, o ar puro, o silêncio, a proximidade do mar, e tudo o mais que se traduza em natureza no espaço urbano, adquirem valor de troca e se constituem em fatores de valorização das localizações no mercado imobiliário urbano. A natureza nesse contexto torna-se uma mercadoria peculiar, a mercadoria verde no dizer de Santana (1999).

Para Lefebvre (1991), a vida urbana compreende mediações originais entre a cidade, o campo e a natureza. Com a grande devastação da natureza na atual fase do capitalismo, elementos que outrora eram abundantes hoje se tornam cada vez mais raros, sobretudo no meio urbano, tais como a água potável, o ar puro e o verde. Por conta disso, há, no espaço urbano, uma recorrência crescente a esses elementos, ainda que estejam, muitas vezes, reduzidos a simulacros da natureza e, como tais, constituem mais uma forma de alimentar os simbolismos e representações dos citadinos sobre a natureza. "É o caso dos parques, dos jardins, das águas cativas" (LEFEBVRE, 1991, p. 68). E acrescenta: “essas mediações não podem ser compreendidas sem os simbolismos e representações (ideológicas, imaginárias) da natureza e do campo como tais pelos citadinos" (LEFEBVRE, 1991, p. 68).

Essa escassez crescente é consequência da produção capitalista de mercadorias. Mas, na medida em que os bens naturais vão se degradando em face dessa produção, contraditoriamente, os mesmos passam a ser "mercadorias verdes". Nesse caso, a condição de mercadoria advém do caráter de sua crescente raridade. Como no espaço urbano, o fator localização constitui um dos principais aspectos de valorização imobiliária (SINGER, 1980), a "oferta" desses bens em determinadas áreas da cidade resulta em aumento dos preços dos lotes. Nesse processo, a natureza escassa, rara, constitui aspecto crucial de valorização. Implica dizer também que a apropriação dessa nova raridade passa a ser privilégio de uns poucos, ou seja, daqueles que podem pagar o alto preço dos lotes "servidos" pelas amenidades naturais. Uma consequência plausível é a crescente diferenciação social no processo de apropriação do espaço urbano em face das disputas pelas amenidades naturais.

Esse retorno à natureza, mesmo que seja muito mais um simulacro, é uma característica do período atual, cada vez mais abalado pelo agravamento dos problemas ambientais. É nesse contexto socioespacial que se fala da natureza como 'mercadoria verde'. Porém,

Muito estranhamente, o direito à natureza (ao campo e à "natureza pura”) entrou para a prática social há alguns anos em favor dos lazeres. [...] a natureza entra para o valor de troca e para a mercadoria; é comprada e vendida. Os lazeres 
comercializados, industrializados, organizados institucionalmente, destroem essa "naturalidade" da qual as pessoas se ocupam a fim de traficá-la e trafegar por ela. A “natureza”, ou aquilo que é tido como tal, aquilo que dela sobrevive, torna-se o gueto dos lazeres, o lugar separado do gozo, a aposentadoria da "criatividade". (LEFEBVRE, 1991, p. 116, grifos do autor).

Nesse sentido, os anúncios publicitários se referem ao Litoral Sul de João Pessoa e, em particular, aos CFHs como se a natureza se apresentasse plenamente nesses espaços. Curiosamente, o retorno à natureza não ocorre com o intuito de conservá-la, e sim, como atributo de valor aos imóveis e empreendimentos que exploram tal 'mercadoria verde'.

Essa visão da natureza como recurso é apontada por distintos autores como um traço marcante da civilização ocidental (PASSMORE, 1995; SOFFIATI, 2008; THOMAS, 2010), que domina o mundo sob o ponto de vista da economia, da tecnologia e da ciência. Atrelado a isso, pode ser acrescentado o ingrediente do caos que vigora nas grandes cidades brasileiras, onde a sensação de insegurança e os problemas de infraestrutura levam as pessoas a buscarem (ou ao menos desejarem) viver sob o signo da tranquilidade e da segurança e, se possível, próximo da natureza. Contudo, seguindo a premissa não mais o que se chamava de natureza virgem ou primeira natureza. Esta é cada vez mais o produto do trabalho humano e, sob tal ponto de vista, "Torna-se cada dia mais culturalizada, mais artificializada, mais humanizada." (SANTOS, 1994, p. 89).

No caso do Litoral Sul da cidade de João Pessoa, observa-se que a apropriação dessas amenidades acompanha a concepção de raridade atribuída aos bens naturais presentes no espaço urbano. Os atributos desse tipo de localização se traduzem num suposto convívio com a natureza, sendo um dos principais aspectos apontados tanto pelos promotores imobiliários quanto pelos moradores, como elementos que qualificam positivamente as características da moradia nesse espaço da cidade.

Não se pode perder de vista que, no que tange à realidade de João Pessoa, a busca frenética por um espaço próximo do mar constitui um fato relativa- mente recente. Foi principalmente a partir do início da década de 1990 que se verificou uma intensificação do processo de verticalização, o qual é bastante concentrado nos bairros da orla marítima no Litoral Norte (VASCONCELOS FILHO, 2003). No Litoral Sul, em vista da baixa densidade urbana, desponta a possibilidade de segmentos sociais de elevado poder aquisitivo usufruírem um leque maior de amenidades naturais e, por que não dizer, de se apropriarem cada vez mais dessas novas raridades.

Assim, observou-se um alto nível de satisfação, por parte dos moradores dos CFHs, em relação a essa questão. Foram citados os seguintes aspectos positivos de se morar nesses subespaços: a boa qualidade do ar, a ausência de poluição sonora, a proximidade de áreas verdes, ventilação, além da citação muito frequente do termo tranquilidade, que certamente pode resumir todos esses aspectos mencionados. A esse respeito, um morador chegou a dizer o seguinte: (Gosto do local onde moro) "porque é agradável, tranquilo e bonito. Porque embora (o condomínio) esteja situado dentro do perímetro urbano, dá aos moradores a sensação de estarem fora da agitação da cidade". Outro morador afirmou gostar do local onde reside por conta do "privilégio de estar próximo do mar".

As falas dos sujeitos da pesquisa chamam a atenção para a dimensão simbólica do espaço urbano (CORRÊA, 1997). A apropriação dos signos de uma natureza cada vez mais escassa é permeada por simbolismos. Morar nessa área se traduz em qualidade de vida e o usufruto das raridades passa a ser visto por moradores como uma questão de status. Em decorrência disso, os resquícios de verde deixados no interior dos CFHs por exigência legal passam a ser explorados como um equipamento de lazer por parte dos moradores, conforme se atesta na imagem da figura 1. É bastante contraditório e ao mesmo tempo sintomático que à medida que o acesso a esses "recursos naturais" é cada vez mais controlado e mediado pelo capital, a sua escassez fica mais evidente e, justamente por conta disso, no espaço urbano, a natureza se transforma em mero simulacro ou mesmo num valor de troca. 
Figura 1. Placa contendo informações para uso das trilhas de área verde no condomínio.

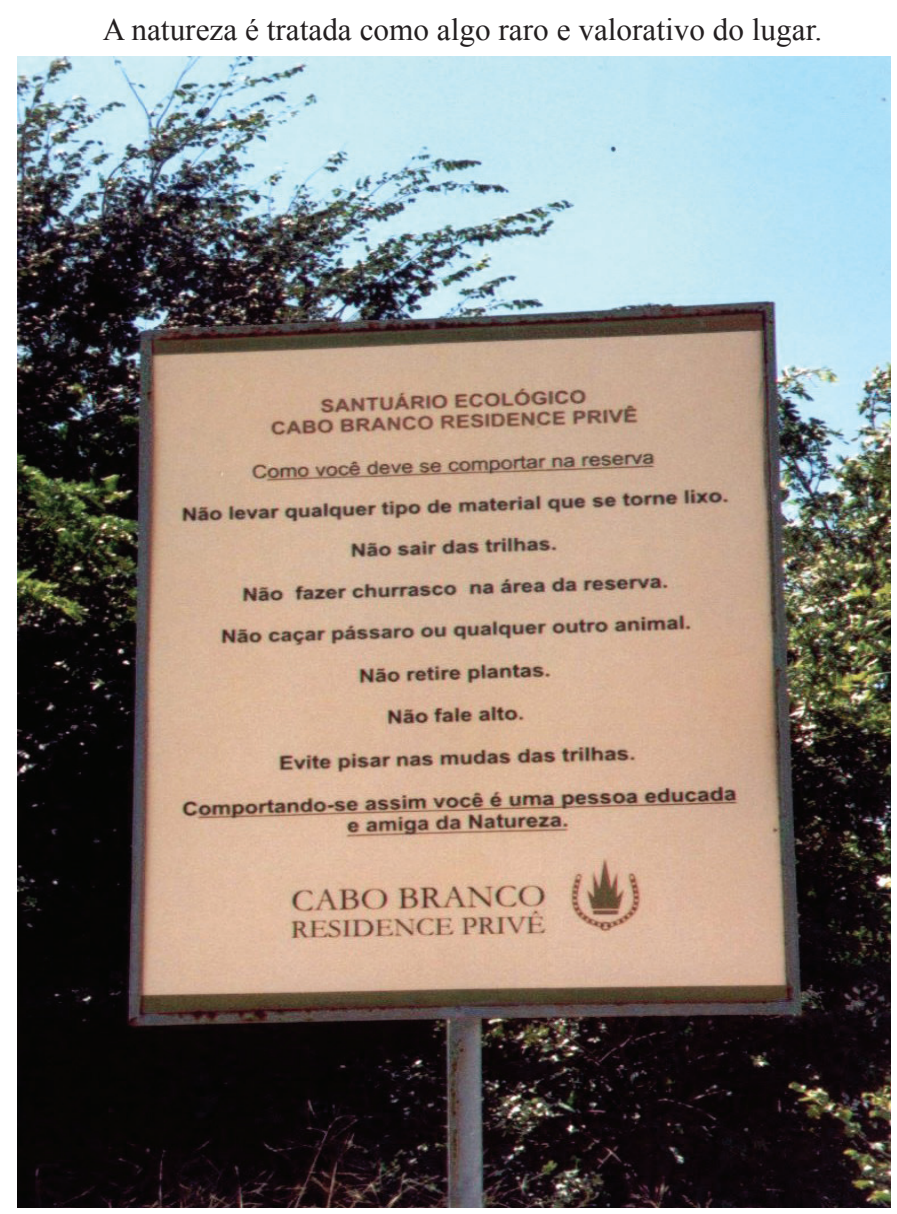

Foto do autor, 2005.

Embora a produção do espaço urbano seja um processo social, a apropriação dessas raridades tende a ser cada vez mais privada (ou em alguns casos, privativa). Assim, Carlos (1999) afirma que a reprodução espacial ocorre a partir da reprodução social e que esse duplo processo produz novas contradições. Além disso, a reprodução espacial atual tem por base a contradição entre a produção social ou coletiva e sua apropriação privada. Desse modo, quanto mais escasso e demandado for um bem, maior valor de troca ele obterá e mais diferenciada socialmente será sua apropriação, o que potencializa a extração de renda fundiária, sendo a natureza (ou a carência dela) um dos vetores desses ganhos. Na medida em que o usufruto da natureza passa a ser mediado pelo mercado, mais tenderão a se acentuar as contradições socioespaciais.

Enquanto objeto de compra e venda, a apropriação de certas características de raridade da natureza resulta em privilégio daqueles que podem pagar o alto preço de um pedaço do espaço urbano. Constatou-se, inclusive, que há amplas áreas nos bairros em análise que estão sendo objeto de especulação imobiliária. Os promotores imobiliários, nesse caso, afirmam que estão à espera de uma maior valorização no mercado. Não há dúvidas de que a presença de amenidades naturais concorre para tal processo.

$\mathrm{O}$ discurso assumido pelos promotores imobiliários de que nos CFHs localizados no Litoral Sul haveria um maior convívio com a natureza se choca com a prática por eles adotada de retirada da cobertura vegetal original, excetuando-se a manutenção legalmente obrigatória de uma área mínima. O plantio de árvores ou no máximo de gramas nos canteiros e jardins em nada parece concordar com esse discurso. Um exemplo cabal dessa dissociação discurso - prática pode ser constatada nas figuras 2 e 3 , a seguir, que evidencia toda essa contradição. 
Figura 2. Vegetação queimada em dezembro de 2004, na área onde foi instalado o Bougainville Residence Privé, nos primeiros meses de 2005

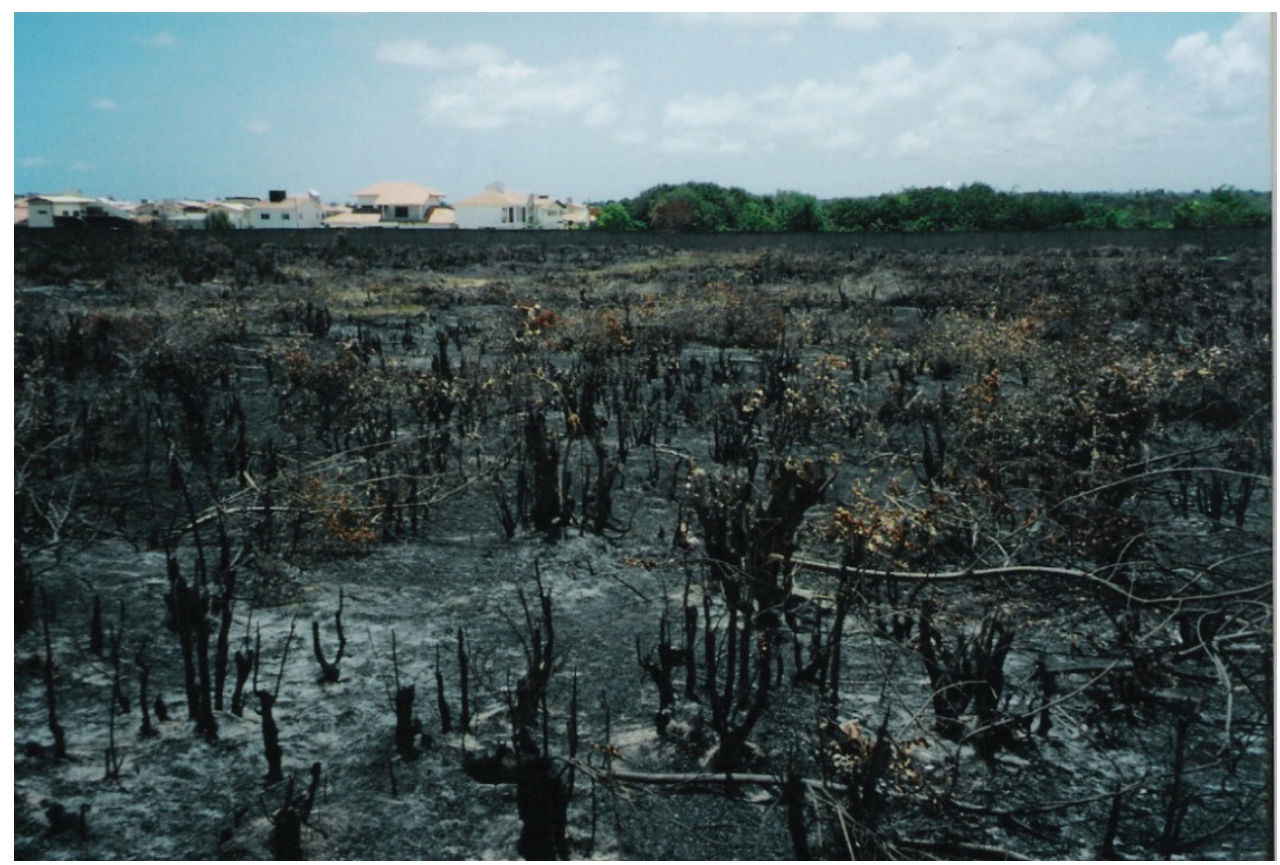

Foto do autor, 2004.

Figura 3. Parte da área queimada, onde foi construído o CFH. Ao fundo, Cabo Branco Residence Privê e trecho de mata preservado

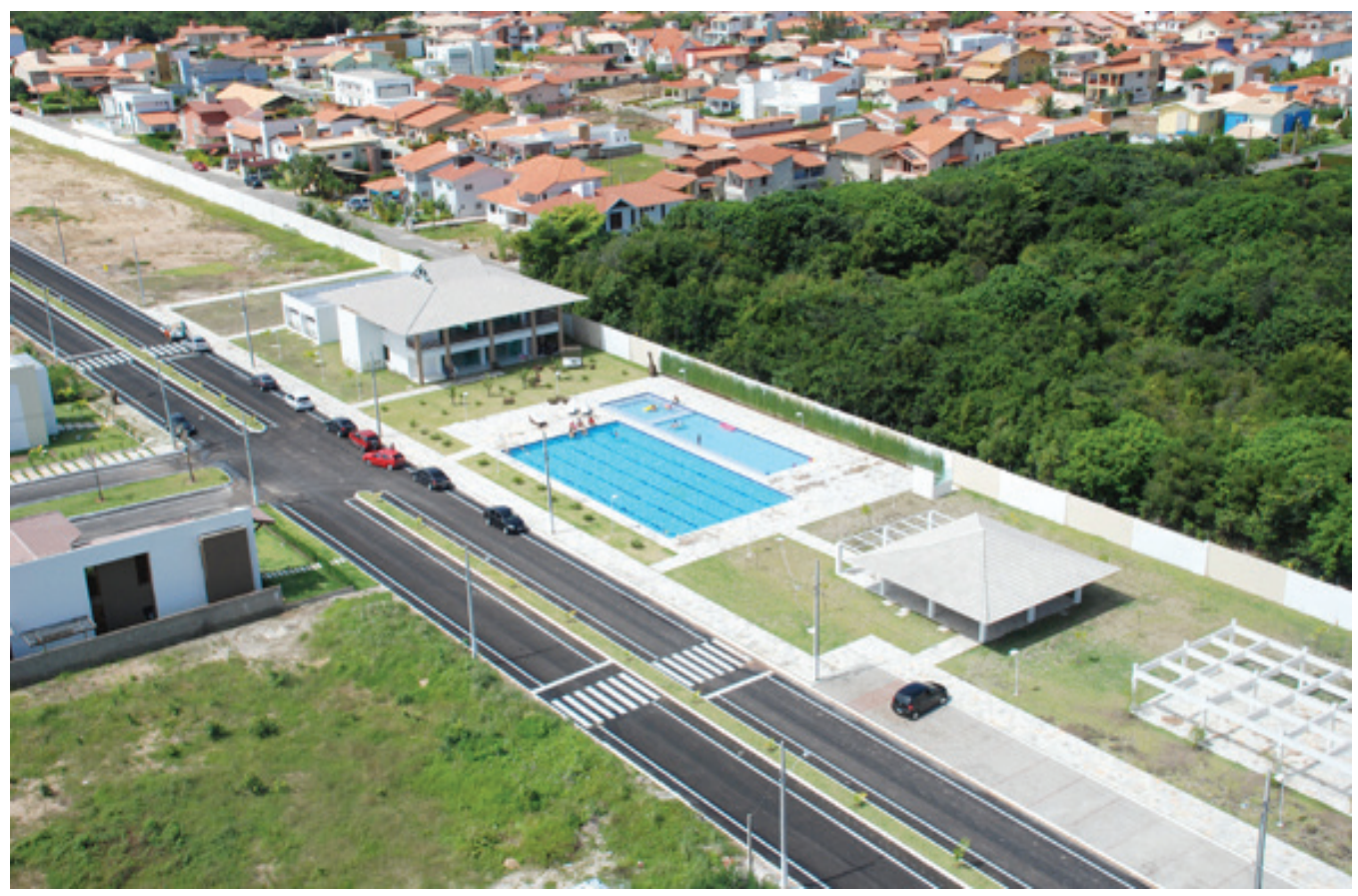

Fonte: http://www.bougainvilleurbanismo.com.br. Acesso em: 04 out. 2011.

Soc. \& Nat., Uberlândia, ano 24 n. 3, 477-488, set/dez. 2012 
Segundo Lefebvre (1976), vive-se uma mudança em que os elementos que constituíam "bens livres" estão sendo convertidos em "novas raridades". Urge reafirmar a importância que o espaço assume na economia política. A vida urbana passa cada vez mais a ser mediada pelos bens naturais enquanto valores de troca. E essa mediação ocorre sob as leis do mercado e, sobretudo, do mercado imobiliário. No momento atual, em que alguns autores chegam a falar de uma suposta perda de importância do espaço em face das transformações impostas pela revolução tecnocientífica e informacional, essa discussão parece rebater tal ponto de vista, ao menos no âmbito do espaço urbano.

Por fim, toda essa discussão aqui levantada perderia sentido se nos espaços urbanos, principalmente das cidades médias e nas metrópoles, os elementos naturais não se apresentassem cada vez mais degradados. É por conta do agravamento dos problemas ambientais de toda ordem que se pode falar da natureza, no espaço urbano, como nova raridade. É importante ter em vista que esses bens naturais considerados raros não se valorizam por si mesmos. A sua valorização advém da possibilidade de apropriação e usufruto, de forma diferenciada, por parte daqueles que podem pagar por esse privilégio. As amenidades naturais não estão (ou não podem estar) disponíveis a todos os habitantes citadinos, senão perderiam o caráter de raridade e, desse modo, não seriam fatores de valorização de determinadas localizações do espaço urbano, a exemplo do que está ocorrendo em subespaços do Litoral Sul da cidade de João Pessoa.

\section{PALAVRAS FINAIS}

Ao longo deste artigo, foram abordados importantes elementos teóricos e práticos referentes à inserção do solo urbano na produção da cidade capitalista e, desse modo, dar pistas para uma melhor compreensão da atuação dos agentes produtores do espaço urbano.

É importante frisar que o a abordagem aqui apresentada partiu do pressuposto de que o espaço urbano não constitui um mero suporte ou palco, mas sim é uma contingência histórica, assim como também o são as possibilidades concretas de extração da renda fundiária. Ter clareza sobre tal concepção teórica é fundamental para os encaminhamentos das ações de planejamento e gestão da cidade atual, entendendo que muitos dos problemas que aí emergem têm nítida dimensão espacial.

O uso capitalista do solo urbano, via de regra, não toma por base o princípio da equidade territorial. Nesse sentido, especulação imobiliária, abertura de novos loteamentos para fins de implantação de CFHs e as inversões do Estado, são ações que, cada vez mais, transformam o solo do Litoral Sul pessoense num espaço apropriado / usado pelos estratos sociais de elevado poder aquisitivo, extraindo assim rendas fundiárias. Os distintos interesses que aí estão em jogo, em grande medida, vão delinear as ações que continuam a tornar o solo urbano numa valorizada mercadoria capitalista. Eles expressam, ao mesmo tempo, os pares dialéticos interesses coletivos versus interesses individuais e conflito entre o público e o privado, comuns na produção e reestruturação da cidade capitalista sob a égide da propriedade privada.

É preciso ficar atento para as mudanças no marco jurídico do uso da cidade, pois, em muitos casos, ao invés de primar pela manutenção das parcas áreas verdes no espaço urbano, permite justamente o contrário. A natureza enquanto raridade não constitui propriamente um problema para os promotores imobiliários. Quanto mais escassa, mais ganha fôlego o discurso da natureza na cidade, ainda que não passe de um simulacro e de um apelo mercadológico potencializador de extração de renda fundiária urbana. Isto, sim, é preocupante para os citadinos, habitantes e usuários do sistema urbano.

\section{REFERÊNCIAS}

CARLOS, Ana Fani A. "Novas" contradições do espaço. In: DAMIANI, Amélia Luisa et al.(org.) $O$ espaço no fim de século: a nova raridade. São Paulo: Contexto, 1999, pp. 62-74.

CORRÊA, Roberto Lobato. Trajetórias geográficas. Rio de Janeiro: Bertrand Brasil, 1997.

HARVEY, David. A justiça social e a cidade. Tradução: Armando C. da Silva. São Paulo: Hucitec, 1980. 
LEFEBVRE, Henri. Espacio y política: el derecho a la ciudad II. Barcelona: Ediciones Península, 1976.

O direito à cidade. Tradução: Rubens

Eduardo Frias. São Paulo: Moraes, 1991.

LOJKINE, Jean. Existe uma renda fundiária urbana? In: FORTI, Reginaldo. (org.) Marxismo e urbanismo capitalista: textos críticos. São Paulo: Ciências Humanas, 1979.

LOW-BEER, J. Doris. Renda da terra: algumas noções básicas para a compreensão do caso urbano. Espaço e Debates. São Paulo, n. 8, p. 31-41, 1983.

PASSMORE, John. Atitudes frente à natureza. Tradução: Christine Rufino-Dabat; Revisão: Edvânia Tôrres Aguiar Gomes e Fabiana dos Santos Firmino. Revista de Geografia. Recife, v. 11, n. 2, jul/dez, p. 91-143. 1995.

RODRIGUES, Arlete Moysés. Moradia nas cidades brasileiras. 10. ed. São Paulo: Contexto, 2003.

SANTANA, Paola Verri de. A mercadoria verde: a natureza. In: DAMIANI, Amélia Luisa. $O$ espaço no fim de século: a nova raridade. São Paulo: Contexto, 1999, pp. 177-189.

SANTOS, Milton. Metamorfoses do espaço habitado. 3. ed. São Paulo: Hucitec, 1994.

SINGER, Paul. O uso do solo urbano na economia capitalista. Boletim Paulista de Geografia. São Paulo, n. 57, p. $77-92,1980$.

SOFFIATI, Arthur. Fundamentos filosóficos e históricos para o exercício da ecocidadania e da ecoeducação. In: LOUREIRO, Carlos Frederico Bernardo et al. (orgs.) Educação ambiental: repensando o espaço da cidadania. 4. ed. São Paulo: Cortez, 2008, p. 23 -68.

SPOSITO, Eliseu Savério. Produção e apropriação da renda fundiária urbana em Presidente Prudente. São Paulo: Edusp, 1990.
SPOSITO, Maria E. Beltrão. O chão arranha o céu: a lógica da reprodução monopolista da cidade. 1991. Tese (Doutorado em Geografia) Universidade de São Paulo. São Paulo.

THOMAS, Keith. O homem e o mundo natural: mudanças de atitude em relação às plantas e aos animais (1500-1800). Tradução: João Roberto Martins Filho. São Paulo: Companhia das Letras, 2010.

TOPALOV, Christian. Análise do ciclo de reprodução do capital investido na produção da indústria da construção civil: capital e propriedade fundiária. In: FORTI, Reginaldo (org.). Marxismo e urbanismo capitalista: textos críticos. São Paulo: Ciências Humanas, 1979.

Ganancias e rentas urbanas: elementos teóricos. Tradução: Fábio Enrique Velásquez Carrillo. Madri: Siglo Veintiuno Editores, 1984.

VASCONCELOS FILHO, João Manoel de. A produção e reprodução do espaço urbano no Litoral Norte de João Pessoa: a atuação dos agentes imobiliários. 2003. Dissertação (Mestrado em Geografia). Universidade Federal de Pernambuco, Recife, 2003. 